Article

\title{
Copper-indium bimetallic catalysts for the selective electrochemical reduction of carbon dioxide
}

\author{
Jiaqi Shao a,b, Yi Wang b, Dunfeng Gao b, Ke Ye a,b,*, Qi Wang c,\#, Guoxiong Wang b \\ a Key Laboratory of Superlight Materials and Surface Technology of Ministry of Education, College of Materials Science and Chemical Engineering, \\ Harbin Engineering University, Harbin 150001, Heilongjiang, China \\ b State Key Laboratory of Catalysis, Dalian National Laboratory for Clean Energy, Dalian Institute of Chemical Physics, Chinese Academy of Sciences, \\ Dalian 116023, Liaoning, China \\ ' Liaoning Key Materials Laboratory for Railway, School of Materials and Engineering, Dalian Jiaotong University, Dalian 116028, Liaoning, China
}

\section{A R T I C L E I N F O}

\section{Article history:}

Received 16 January 2020

Accepted 27 February 2020

Published 5 September 2020

\section{Keywords:}

$\mathrm{CO}_{2}$ electroreduction reaction

Copper

Indium

Electrodeposition

Formate

\begin{abstract}
A B S T R A C T
Copper-indium bimetallic catalysts with a dendritic structure are fabricated by a two-step electrodeposition method using a hydrogen evolution template for the $\mathrm{CO}_{2}$ electroreduction reaction $\left(\mathrm{CO}_{2} \mathrm{RR}\right)$. The dendritic $\mathrm{Cu}-\mathrm{In}-30$ catalyst electrodeposited for $30 \mathrm{~min}$ shows the highest specific surface area and exposes the most active sites, resulting in improved $\mathrm{CO}_{2} \mathrm{RR}$ activity. The dendritic Cu-In-30 catalyst exhibits distinctly higher formate partial current density $(42.0 \mathrm{~mA} \mathrm{~cm}-2)$ and Faradaic efficiency (87.4\%) than those of the In-30 catalyst without the dendritic structure (the formate partial current density and Faradaic efficiency are $4.6 \mathrm{~mA} \mathrm{~cm}^{-2}$ and $57.0 \%$, respectively) at $-0.85 \mathrm{~V}$ vs. reversible hydrogen electrode, ascribed to the increased specific surface area. The $\mathrm{Cu}-\mathrm{In}-30$ catalyst can maintain stable performance for $12 \mathrm{~h}$ during the $\mathrm{CO}_{2} \mathrm{RR}$. In addition, the intrinsic current density of $\mathrm{Cu}-\mathrm{In}-30$ with the dendritic structure $\left(4.8 \mathrm{~mA} \mathrm{~cm}^{-2}\right)$ is much higher than that of In-30 without the dendritic structure $\left(2.1 \mathrm{~mA} \mathrm{~cm}^{-2}\right)$, indicating that the dendritic structure promotes the $\mathrm{CO}_{2} \mathrm{RR}$, possibly due to additional coordination unsaturated atoms.
\end{abstract}

(C) 2020, Dalian Institute of Chemical Physics, Chinese Academy of Sciences. Published by Elsevier B.V. All rights reserved.

\section{Introduction}

With the excessive consumption of fossil fuels, global warming caused by carbon dioxide $\left(\mathrm{CO}_{2}\right)$ is receiving increasing attention [1-7]. The $\mathrm{CO}_{2}$ electroreduction reaction $\left(\mathrm{CO}_{2} \mathrm{RR}\right)$, which utilizes renewable energy sources, is a feasible strategy for converting $\mathrm{CO}_{2}$ into useful fuel and chemicals, such as carbon monoxide, formate, and methane [8-14]. Particularly, formate with a high hydrogen content is usually used as liquid fuel in fuel cells. Moreover, formate can also be directly used for fabric processing, tanning, textile printing, and silage storage, as well as metal surface treatment agents, rubber additives, and industrial solvents [5,15-18]. Nonetheless, the $\mathrm{CO}_{2} \mathrm{RR}$ process is generally accompanied by high energy consumption owing to the sluggish kinetics and low selectivity toward formate production. Therefore, the design of efficient catalysts is crucial for promoting the $\mathrm{CO}_{2} \mathrm{RR}$ current density and selectivity toward formate at low overpotentials.

\footnotetext{
* Corresponding author. E-mail: yeke@hrbeu.edu.cn

\# Corresponding author. E-mail: qiwang@djtu.edu.cn

This work was supported by the National Natural Science Foundation of China (21802124 and 91845103), Joint Research Fund Liaoning-Shenyang National Laboratory for Materials Science (20180510035), the China Postdoctoral Science Foundation (2018M630307 and 2019T120220) and Excellent Youth Project of Natural Science Foundation of Heilongjiang Province of China (YQ2019B002).

DOI: 10.1016/S1872-2067(20)63577-X | http://www.sciencedirect.com/science/journal/18722067 | Chin. J. Catal., Vol. 41, No. 9, September 2020
} 
Currently, precious metals such as gold and palladium can effectively convert $\mathrm{CO}_{2}$ into $\mathrm{CO}$ or formate [19-22]; however, their high cost greatly limits their application in $\mathrm{CO}_{2} \mathrm{RR}$. Indium and its alloys have already been proven to possess high catalytic properties for $\mathrm{CO}_{2} \mathrm{RR}$ to afford formate with a low cost [23-29]. However, the current density and selectivity of these catalysts are unsatisfactory at low overpotentials. Furthermore, copper-based catalysts exhibit appropriate selectivity toward formate production, although they usually suffer from poor stability in a short duration. Thus, the current density and stability of indium and copper require further enhancements $[30,31]$. One promising solution involves combining copper with indium to construct a bimetallic catalyst, which can increase the current density and stability for the selective $\mathrm{CO}_{2} \mathrm{RR}$ to form formate at low overpotentials, owing to the synergistic effect between indium and copper.

In this work, we fabricated the copper-indium bimetallic catalysts with a dendritic structure by a two-step electrodeposition method for $\mathrm{CO}_{2} \mathrm{RR}$. The electrochemical deposition using a hydrogen evolution template could effectively form the dendritic structure, which was able to increase the specific surface area and activity of the catalysts due to the superior three-dimensional (3D) open structure [16,32]. Moreover, the unique copper-indium double-layer structure could also improve the stability of $\mathrm{CO}_{2} \mathrm{RR}$. The relationship between the electrodeposition time of indium and the electrochemically active surface areas (ESAs) was investigated. The $\mathrm{Cu}-\mathrm{In}-30$ catalyst with the electrodeposition time of $30 \mathrm{~min}$ had the most electrochemical active sites; therefore, it could greatly enhance the catalytic activity for $\mathrm{CO}_{2} \mathrm{RR}$. The $\mathrm{Cu}$-In- 30 catalyst exhibited a formate partial current density of $42.0 \mathrm{~mA} \mathrm{~cm}^{-2}$ and formate Faradaic efficiency of $87.4 \%$ at $-0.85 \mathrm{~V}$ vs. reversible hydrogen electrode (RHE) and maintained a stable performance for $12 \mathrm{~h}$ during the $\mathrm{CO}_{2} \mathrm{RR}$ test in a $0.1 \mathrm{~mol} \mathrm{~L}^{-1} \mathrm{KHCO}_{3}$ solution. In addition, the ESA-corrected current density of $\mathrm{Cu}-\mathrm{In}-30$ with the dendritic structure for formate $(4.8 \mathrm{~mA} \mathrm{~cm}-2)$ was much higher than that of In-30 without the dendritic structure $(2.1 \mathrm{~mA}$ $\mathrm{cm}^{-2}$ ), indicating that the dendritic structure could increase the intrinsic activity.

\section{Experimental}

\subsection{Materials}

Indium sulfate $\left(\mathrm{In}_{2}\left(\mathrm{SO}_{4}\right)_{3}, 99.0 \%\right)$, boric acid $\left(\mathrm{H}_{3} \mathrm{BO}_{3}\right.$, $99.5 \%)$, potassium sulfate $\left(\mathrm{K}_{2} \mathrm{SO}_{4}, 99.0 \%\right)$, and potassium bicarbonate $\left(\mathrm{KHCO}_{3}\right)$ were purchased from Sinopharm Chemical Reagent Co. Copper sulfate $\left(\mathrm{CuSO}_{4}, 99.0 \%\right)$, hydrochloric acid $(\mathrm{HCl})$, sulfuric acid $\left(\mathrm{H}_{2} \mathrm{SO}_{4}\right)$, and acetone $\left(\mathrm{CH}_{3} \mathrm{COCH}_{3}\right)$ were purchased from Tianjin Kermel Chemical Reagent Co., Ltd.

\subsection{Materials preparation}

The catalyst was prepared by a two-step electrodeposition method. The copper foam was cut into a square with an area of $1 \mathrm{~cm}^{2}(1 \mathrm{~cm} \times 1 \mathrm{~cm})$ and placed into the acetone and ethanol mixed solution for $30 \mathrm{~min}$ to clean the grease on the surface by ultrasonic treatment. The copper foam was immersed into the $6 \mathrm{~mol} \mathrm{~L}^{-1}$ hydrochloric acid solution for $15 \mathrm{~min}$ to etch off the oxides on the surface. The cleaned copper foam was used as the working electrode, and platinum wire and $\mathrm{Ag} / \mathrm{AgCl}$ electrode were used as the counter electrode and the reference electrode, respectively. The electrodes were immersed in a $0.1 \mathrm{~mol} \mathrm{~L}^{-1}$ copper sulfate and $1 \mathrm{~mol} \mathrm{~L}^{-1}$ sulfuric acid mixed solution that was constantly stirred to maintain the balance of electrolyte concentration. Dendritic copper was produced by the hydrogen template method that involves applying a current of $-2.5 \mathrm{~A}$ $\mathrm{cm}^{-2}$ to the working electrode for $20 \mathrm{~s}$, which can cause the electrodeposited copper to assume an irregular shape. Subsequently, the copper foam with the dendritic copper on its surface served as the working electrode; the counter electrode was platinum wire, and $\mathrm{Ag} / \mathrm{AgCl}$ served as the reference electrode. The electrodes were placed into the electrolyte containing 3 mmol L-1 indium sulfate, $0.1 \mathrm{~mol} \mathrm{~L}^{-1}$ potassium sulfate, and 15 $\mathrm{mM}$ boric acid. The current on the working electrode was -30 $\mathrm{mA} \mathrm{cm}-2$, applied for $1.5,7.5,15,30$, and $60 \mathrm{~min}$, and the obtained electrodes were denoted as Cu-In-1.5, Cu-In-7.5, Cu-In-15, Cu-In-30, and Cu-In-60, respectively. The Cu-In-30 catalyst exhibited the best performance in ensuring that indium completely covers the surface of dendritic copper. For comparison, indium electrodeposited on non-dendritic copper was prepared by electrodeposition in the solution containing 3 mmol L-1 indium sulfate, $0.1 \mathrm{~mol} \mathrm{~L}^{-1}$ potassium sulfate, and 15 mmol L-1 boric acid with a current of $-30 \mathrm{~mA} \mathrm{~cm}^{-2}$ for $30 \mathrm{~min}$ on the copper foam, which was denoted as In-30. The prepared catalysts were washed with water and ethanol to remove the residual impurities, after which they were dried in a vacuum oven.

\subsection{Physicochemical characterizations}

X-ray diffraction (XRD Empyrean-100) measurement was used to detect the change in indium crystallinity as the electrodeposition time increased in the range of $10^{\circ}-90^{\circ}$. The process of indium gradually covering the dendritic copper surface and the distribution of copper and indium on the surface of the catalyst was observed by scanning electron microscopy (SEM, JSM-7800F). After ultrasonic dispersion in ethanol, the catalyst was dropped onto a molybdenum mesh carbon film for observing the microstructure of the catalyst sample using high-resolution transmission electron microscopy (HRTEM, JEM-2100). The catalysts were analyzed by X-ray photoelectron spectroscopy (XPS, ESCALAB 250Xi) that used the C $1 s$ peak located at $284.6 \mathrm{eV}$ to calibrate the binding energy positions to analyze the valence state of the catalyst. The actual loading of indium was measured by inductively coupled plasma optical emission spectrometry (ICP-OES, 7300DV).

\subsection{Electrochemical measurements}

An H-cell filled with $40 \mathrm{~mL}$ of the $0.1 \mathrm{~mol} \mathrm{~L}^{-1} \mathrm{KHCO}_{3}$ solution was used for the $\mathrm{CO}_{2} \mathrm{RR}$ measurements, and the compartments were separated by a Nafion 115 membrane. In the two compartments of the $\mathrm{H}$-cell, $95 \% \mathrm{CO}_{2}-5 \% \mathrm{~N}_{2}$ gas was purged at a 
flow rate of $20 \mathrm{~mL} \mathrm{~min}^{-1}$ for $30 \mathrm{~min}$ to saturate the electrolyte. The $\mathrm{pH}$ of the saturated electrolyte was 6.8 . The electrolyte was continuously stirred for a maximum mass transfer rate. The prepared catalyst was used as the working electrode, $\mathrm{Ag} / \mathrm{AgCl}$ was placed in the vicinity of the working electrode as the reference electrode, and platinum was placed in the compartment of the cell as the counter electrode. All potential calculations are obtained by $i R$ compensation and are represented with RHE. Prior to the $\mathrm{CO}_{2} \mathrm{RR}$ test, a potential of $-0.75 \mathrm{~V}$ vs. RHE was applied for $20 \mathrm{~min}$ to reduce the indium oxide on the catalyst surface to metallic indium.

The generated gases during the $\mathrm{CO}_{2} \mathrm{RR}$, such as $\mathrm{CO}$, entered into an on-line micro gas chromatograph (GC) (Agilent 490) equipped with a thermal conductivity detector and Molsieve $5 \mathrm{~A}$ column to analyze the gas product. Electrolysis was carried out for $30 \mathrm{~min}$ at each potential. At the end of the constant potential electrolysis, the electrolyte was collected and the liquid-phase product was detected using a Bruker AVANCE III $400 \mathrm{MHz}$ nuclear magnetic resonance spectrometer. The concentration of the liquid product (only formate in this work) was determined from the linear relationship of the area ratio between the known concentration of sodium 3-(trimethylsilyl)1-propanesulfonate (Sigma-Aldrich) and the product to be measured. Therefore, the corresponding Faradaic efficiency can be calculated according to the following formula:

$$
F_{\mathrm{f}}=C \times V \times N \times F \times I^{-1} \times t^{-1} \text {, }
$$

where $F_{\mathrm{f}}$ is the Faradaic efficiency of formate (\%), $C$ is the concentration of formate ( $\left.\mathrm{mol} \mathrm{L}^{-1}\right), V$ is the volume of the electrolyte ( $40 \mathrm{~mL}), N$ is the number of reaction transfer electrons (2), $F$ is the Faradaic constant $\left(96485 \mathrm{C} \mathrm{mol}^{-1}\right), I$ is the current density $(\mathrm{mA} \mathrm{cm}-2)$, and $t$ is the total duration of the reaction at a single potential (1800 s).

After each constant potential electrolysis test, the two compartments were cleaned with water, after which a fresh $0.1 \mathrm{~mol}$ $\mathrm{L}^{-1} \mathrm{KHCO}_{3}$ electrolyte was poured and $\mathrm{CO}_{2}$ gas was purged for $30 \mathrm{~min}$ to saturate the electrolyte.

The ESAs of different samples were determined by cyclic voltammetry (CV) in $5 \mathrm{mmol} \mathrm{L}^{-1} \mathrm{~K}_{3} \mathrm{Fe}(\mathrm{CN})_{6}$ and $0.1 \mathrm{~mol} \mathrm{~L}^{-1} \mathrm{KCl}$ solution, with the prepared catalyst employed as the working electrode and the platinum wire as the counter electrode;
$\mathrm{Ag} / \mathrm{AgCl}$ was employed as the reference electrode. The ESA was obtained using the Randles-Sevcik equation $[33,34]$ :

$$
I_{\mathrm{p}}=\left(2.36 \times 10^{5}\right) n^{3 / 2} \times A \times D^{1 / 2} \times C \times v^{1 / 2},
$$

where $I_{\mathrm{p}}$ is the peak current, $n$ is the number of reaction transfer electrons (1), $D$ is the reaction-diffusion coefficient $(4.34 \times$ $\left.10^{-6} \mathrm{~cm}^{2} \mathrm{~s}^{-1}\right), A$ is the electrochemical surface area $\left(\mathrm{cm}^{2}\right), C$ is the concentration of $\mathrm{K}_{3} \mathrm{Fe}(\mathrm{CN})_{6}\left(5 \times 10^{-6} \mathrm{~mol} \mathrm{~cm}^{-3}\right)$, and $V$ is the $\mathrm{CV}$ scan rate $\left(5 \mathrm{mV} \mathrm{s}^{-1}\right)$.

\section{Results and discussion}

Figure 1a shows the XRD patterns of $\mathrm{Cu}-\mathrm{In}-1.5, \mathrm{Cu}-\mathrm{In}-7.5$, $\mathrm{Cu}-\mathrm{In}-15, \mathrm{Cu}-\mathrm{In}-30$, and Cu-In-60. Metallic copper on the surface of the copper foam can be observed at $43.2^{\circ}, 50.5^{\circ}$, and 74.1 ${ }^{\circ}$ (PDF 04-0836). As the electrodeposition time on the copper foam increases, it can be clearly observed that the diffraction peaks of indium at $2 \theta=33.0^{\circ}, 36.3^{\circ}$, and $39.2^{\circ}(\mathrm{PDF}$ 05-0642) gradually increase, which indicates that the content of indium is increased. Since indium is rapidly oxidized in the air, a diffraction peak of $\mathrm{In}_{2} \mathrm{O}_{3}$ (PDF 06-0416) is observed in the XRD patterns. Similarly, the XRD patterns of In-30 show diffraction peaks of indium and $\mathrm{In}_{2} \mathrm{O}_{3}$ (Fig. S1). When the dendritic copper is deposited in the first step, the copper on the surface is oxidized spontaneously to CuO (PDF 44-0706) and is reflected in the XRD patterns. For Cu-In-1.5, indium is formed by electrodeposition, which cannot completely cover the surface of the dendritic copper; therefore, a small amount of $\mathrm{Cu}_{2} \mathrm{O}$ (PDF 05-0667) is formed. To determine the valence state of the indium surface, XPS analysis was carried out. Figure 1b shows the XPS spectra of $\mathrm{Cu}$-In-30; the binding energy of the $\operatorname{In}^{0} 3 d_{5 / 2}$ orbital is $444.7 \mathrm{eV}$, and the binding energy of the $\mathrm{In}^{3+} 3 d_{5 / 2}$ orbital is $445.7 \mathrm{eV}$, which are consistent with the previously reported values [35,36].

Figure 2 shows the SEM images of bare copper, Cu-In-1.5, Cu-In-7.5, Cu-In-15, Cu-In-30, Cu-In-60, and In-30. The structure of the dendritic copper can be clearly seen in Fig. S2, which is made up of many small copper particles. Figures $2 \mathrm{a}$ and $2 \mathrm{~b}$ indicate that the bare copper foam surface is smooth. Figure 2c shows that $\mathrm{Cu}-\mathrm{In}-1.5$ still maintains a good dendritic structure because the electrodeposition time is only $1.5 \mathrm{~min}$ at $-30 \mathrm{~mA}$
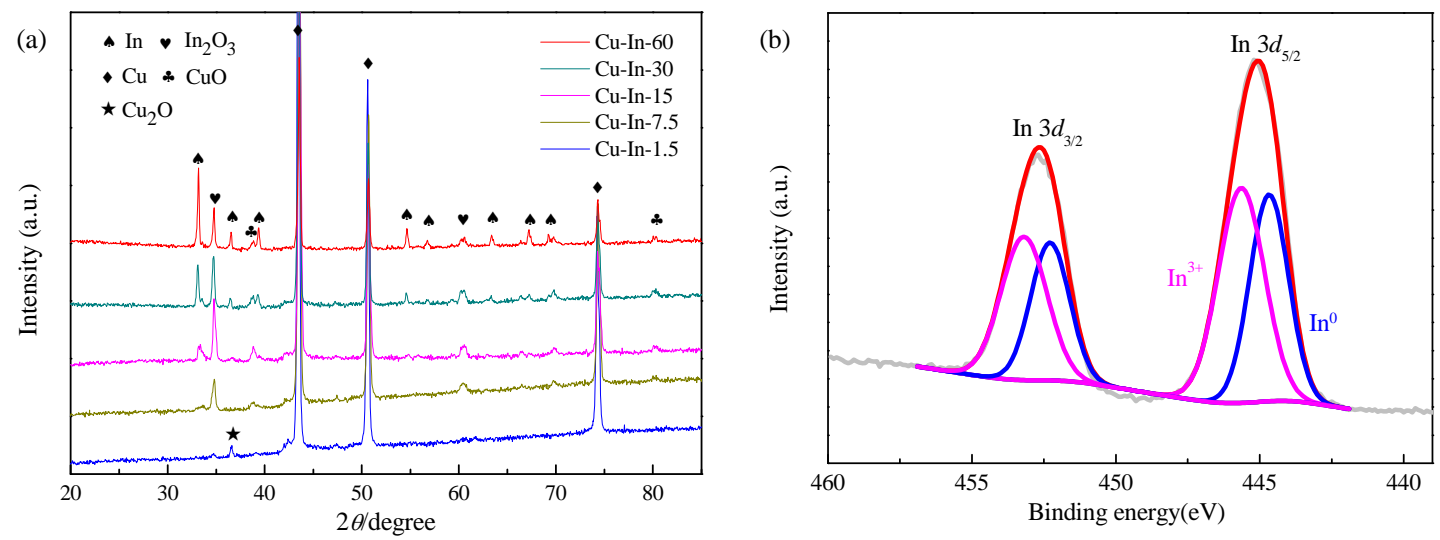

Fig. 1. XRD patterns of the electrode-electrodeposited indium metal on the dendritic copper for various periods (a), and the In $3 d$ XPS spectra of Cu-In-30 (b). 

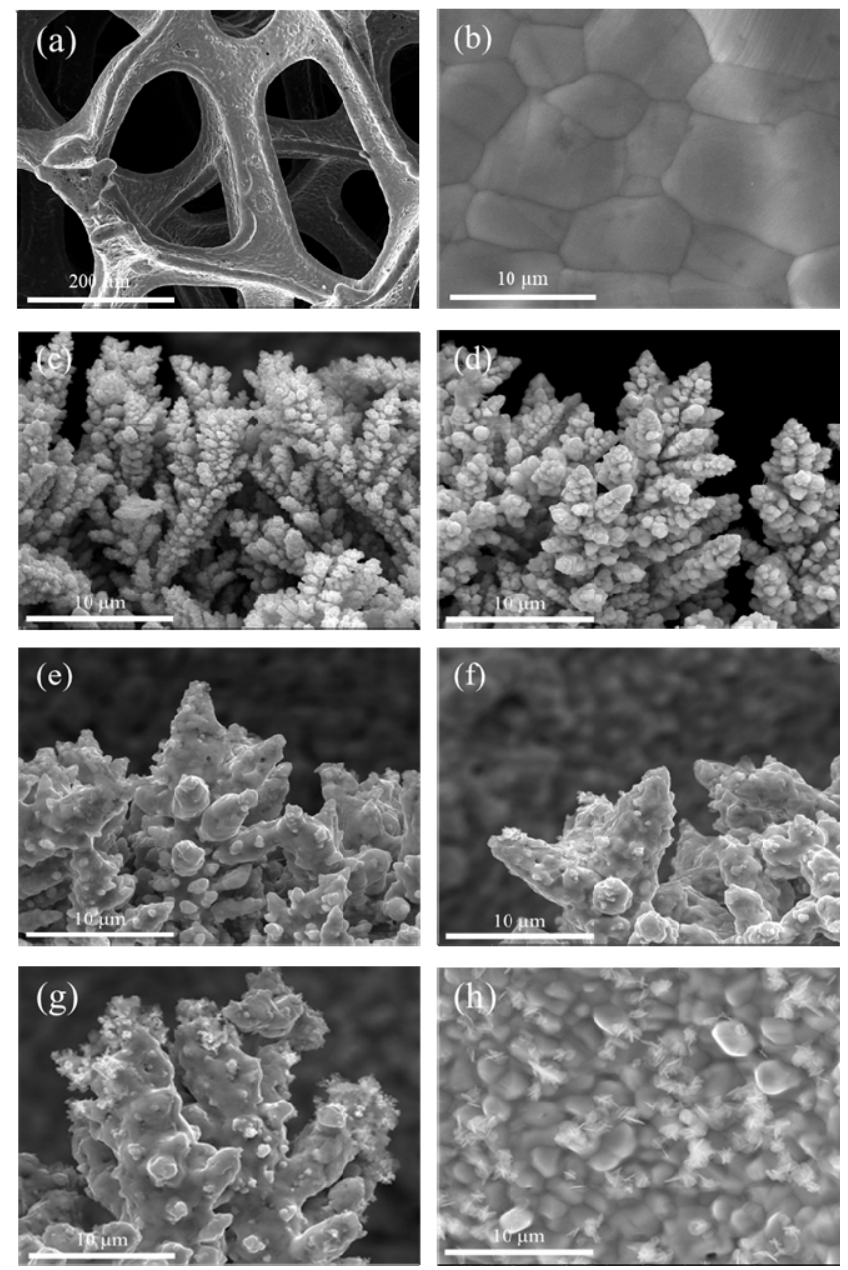

Fig. 2. SEM images of bare copper before electrodeposition $(a, b)$, the electrodes with electrodeposited indium on the dendritic copper structure for $1.5 \mathrm{~min}$ (c), $7.5 \mathrm{~min}$ (d), $15 \mathrm{~min}$ (e), $30 \mathrm{~min}$ (f), and $60 \mathrm{~min}$ (g), and the electrode with directly electrodeposited indium on the copper foam (h).

$\mathrm{cm}^{-2}$, and the electrodeposited indium does not cover the structure of the dendritic copper completely. However, as the deposition time increases, the content of the metallic indium increases and the electrodeposited indium fills the gap between the dendritic copper particles [16]; thus, the graininess of the catalyst gradually decreases, as shown in Fig. 2c-2g. For $\mathrm{Cu}$-In-30, indium completely covers the surface of the dendritic copper and maintains a dendritic structure well with maximizing the active site [37-39]. In the $\mathrm{Cu}-\mathrm{In}-60$ catalyst, since the amount of indium is sufficiently large to slightly destroy the dendritic structure, the active site cannot be fully utilized. By firstly depositing a dendritic copper structure and subsequently electrodepositing the metallic indium, the specific surface area can be maximized. As shown in Fig. $2 \mathrm{~h}$, In-30 is obtained only by electrodepositing indium, which does not have a dendritic structure and is formed by stacking many small particles on the flat copper foam surface.

To survey the microstructure of the $\mathrm{Cu}-\mathrm{In}-30$ catalyst, the TEM image of the Cu-In-30 catalyst was obtained and is shown in Fig. 3a. The characteristic space of the lattice in indium is affected by HRTEM and destroyed immediately; therefore, the
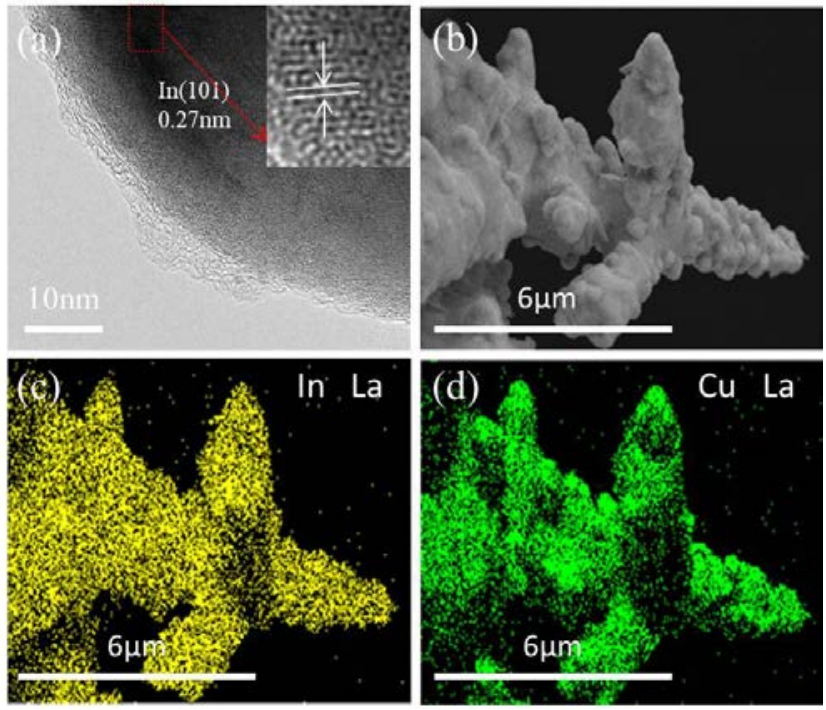

Fig. 3. HRTEM images of the Cu-In-30 catalyst (a), SEM image of the Cu-In-30 catalyst (b), and corresponding EDX elemental maps (c, d).

local area can only be enlarged to observe the characteristic space of the lattice, which is $0.27 \mathrm{~nm}$ and conforms well to the (101) plane of indium. Figures 3b-3d show the energy dispersive X-ray (EDX) elemental maps of the $\mathrm{Cu}$-In-30 catalyst, indicating that indium is evenly distributed on the dendritic copper structure. The EDX elemental maps of Cu-In-1.5, Cu-In-7.5, Cu-In-15, Cu-In-60, and In-30 are shown in Fig. S3, and it can be clearly seen that as the electrodeposition time increases, the indium coverage on the dendritic copper surface gradually increases, while in the In-30 catalyst, indium is simply laid flat on the surface of the copper foam. Compared with the In-30 catalyst, the $\mathrm{Cu}-\mathrm{In}-30$ catalyst has a higher specific surface area and also exposes more active sites.

To understand the effect of the electrodeposition time of indium on the $\mathrm{CO}_{2} \mathrm{RR}$ performance, the Faradaic efficiencies of all the catalysts at different potentials were determined and are shown in Fig. 4a. All the catalysts start to produce formate at $-0.65 \mathrm{~V}$ vs. $\mathrm{RHE}$ in a $\mathrm{CO}_{2}$-saturated $0.1 \mathrm{~mol} \mathrm{~L}^{-1} \mathrm{KHCO}_{3}$ solution. The Faradaic efficiency of $\mathrm{Cu}-\mathrm{In}-1.5$ for formate is only $21.5 \%$ at $-0.65 \mathrm{~V}$ vs. RHE, and with the prolongation of the electrodeposition for indium, the Faradaic efficiencies of $\mathrm{Cu}-\mathrm{In}-7.5$, Cu-In-15, Cu-In-30, and Cu-In-60 for formate correspond to $31.0 \%, 40.8 \%, 46.3 \%$, and $31.4 \%$, respectively. When the potential is negatively shifted from -0.65 to $-1.05 \mathrm{~V}$ vs. RHE, the Faradaic efficiency for formate of each sample gradually increases and reaches the highest value at $-0.85 \mathrm{~V}$ vs. RHE. When the potential continues to shift negatively, the Faradaic efficiency for formate of each sample basically remains unchanged. Moreover, the formate Faradaic efficiency of $\mathrm{Cu}-\mathrm{In}-30$ is always the highest under each potential condition. Thus, the $\mathrm{Cu}-\mathrm{In}-30$ catalyst shows the highest formate Faradaic efficiency that reaches $87.4 \%$ at $-0.85 \mathrm{~V}$ vs. RHE. The formate Faradaic efficiency of Cu-In-60 under each potential condition is slightly lower than that of $\mathrm{Cu}-\mathrm{In}-30$, because an overly high amount of indium is electrodeposited so the gaps between the small particles of dendritic copper are filled, and the active sites are less 

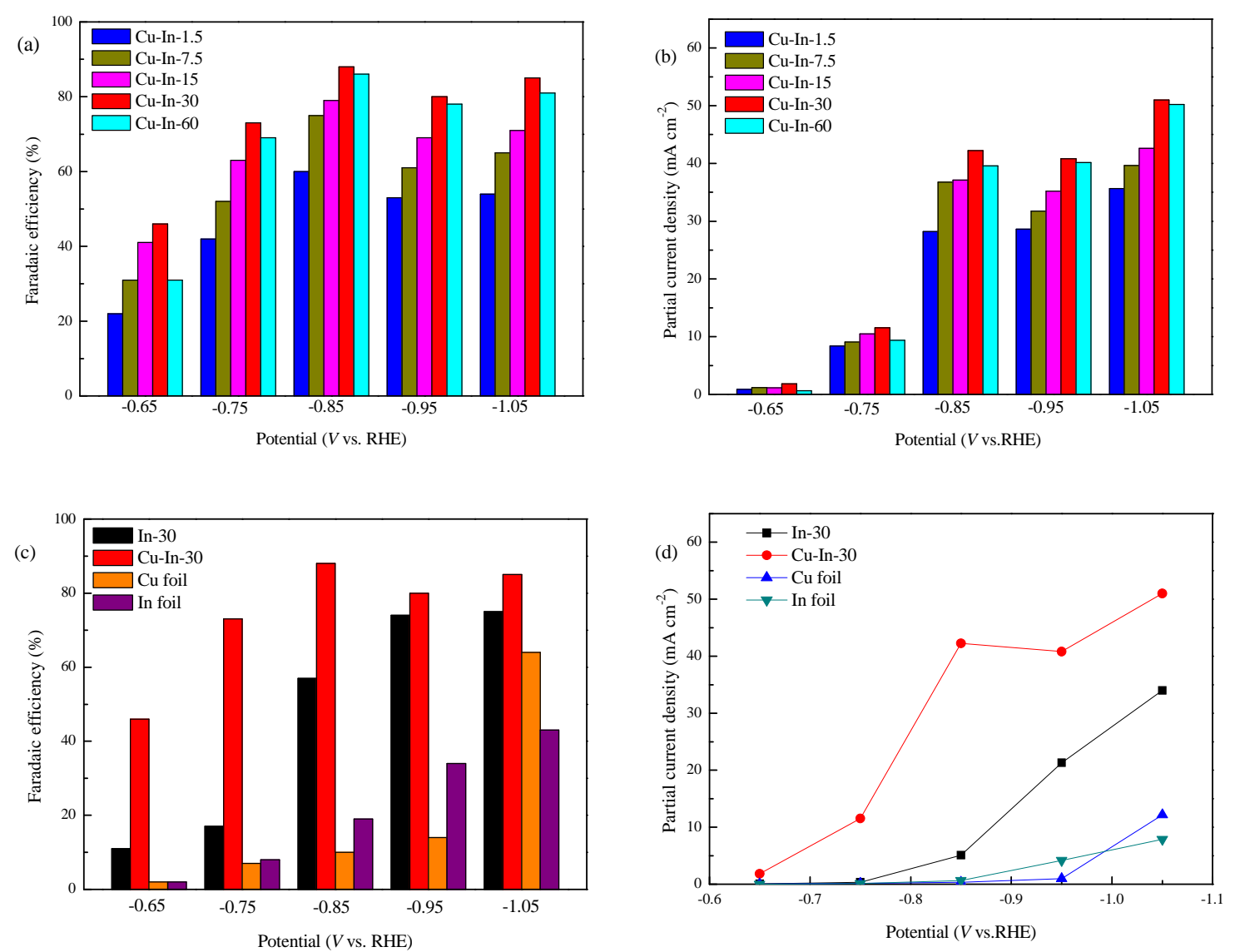

Fig. 4. Faradaic efficiency (a) and partial current density for formate (b) on the dendritic Cu-In electrodes with various electrodeposition times; Faradaic efficiencies (c) and partial current densities (d) for formate on the Cu-In-30, In-30, copper foil, and indium foil electrodes.

than those in the Cu-In-30 catalyst. From -0.65 to $-1.05 \mathrm{~V}$ vs. RHE, the Faradaic efficiencies of the by-products, such as $\mathrm{H}_{2}$ and CO, are shown in Fig. S4, which further explains that the metallic indium on the dendritic copper can selectively convert $\mathrm{CO}_{2}$ to formate and effectively prevent the production of $\mathrm{CO}$ and $\mathrm{H}_{2}$.

The partial current densities of $\mathrm{H}_{2}$ and $\mathrm{CO}$ by the other catalysts from -0.65 to $-1.05 \mathrm{~V}$ vs. RHE are shown in Fig. S5. All the catalysts show low partial current densities of formate $(<2 \mathrm{~mA}$ $\mathrm{cm}^{-2}$ ) at $-0.65 \mathrm{~V}$ vs. RHE. As the potential continues to shift negatively, the conversion of $\mathrm{CO}_{2}$ to formate gradually becomes the dominant reaction. The partial current density of formate provided by $\mathrm{Cu}-\mathrm{In}-30$ reaches $42.0 \mathrm{~mA} \mathrm{~cm}-2$. Interestingly, at each potential, the partial current density of formate displays a volcano shape, and $\mathrm{Cu}$-In-30 always maintains the highest value. Therefore, the conversion of $\mathrm{CO}_{2}$ to formate can be effectively promoted by electrodepositing indium on the dendritic copper for $30 \mathrm{~min}$.

To convincingly explain why the dendritic copper structure can effectively convert $\mathrm{CO}_{2}$ to formate, the Faradaic efficiency of formate produced by the $\mathrm{Cu}-\mathrm{In}-30$ catalyst is compared with those toward formate shown by the In-30, copper foil, and indium foil catalysts from -0.65 to $-1.05 \mathrm{~V}$ vs. RHE in Fig. $4 \mathrm{c}$. The Faradaic efficiencies of formate produced by In-30, copper foil, and indium foil are only $11.0 \%, 2.2 \%$, and $2.1 \%$ at $-0.65 \mathrm{~V}$ vs. RHE, respectively, which are much lower than that of formate produced by $\mathrm{Cu}-\mathrm{In}-30$. As the potential shifts continuously to more negative values, the formate Faradaic efficiency of Cu-In-30 is always higher than those of In-30, copper foil, and indium foil at each potential. The Faradaic efficiency of $87.4 \%$ toward formate is shown by $\mathrm{Cu}-\mathrm{In}-30$ at $-0.85 \mathrm{~V}$ vs. RHE, while the formate Faradaic efficiencies of In-30, copper foil, and indium foil are only $57.0 \%, 9.6 \%$, and $19.2 \%$, respectively, which highlights the importance of the dendritic structure. The difference between the four catalysts is not only reflected in the Faradaic efficiency of formate, but also in the partial current density of formate, as shown in Fig. 4d. At each potential, the $\mathrm{Cu}-\mathrm{In}$-30 electrode provides a higher current density than the In-30, copper foil, and indium foil catalysts between $-0.65 \mathrm{~V}$ to $-1.05 \mathrm{~V}$ vs. RHE. The difference between the four catalysts reaches a maximum at $-0.85 \mathrm{~V}$ vs. RHE. The partial current density of Cu-In-30 is $42.0 \mathrm{~mA} \mathrm{~cm}-2$, but the partial current densities of the In-30, copper foil, and indium foil are $4.6 \mathrm{~mA}$ $\mathrm{cm}^{-2}, 0.4 \mathrm{~mA} \mathrm{~cm}^{-2}$, and $0.7 \mathrm{~mA} \mathrm{~cm}^{-2}$, respectively, which is because the dendritic structure enables the catalyst to have a relatively high specific surface area and additional active sites.

The ESAs were used to explain why the $\mathrm{Cu}-\mathrm{In}$-30 electrode exhibits the highest $\mathrm{CO}_{2} \mathrm{RR}$ performance (Fig. 5). CV measurement was employed for the ESA tests from $0.55 \mathrm{~V}$ to $1.25 \mathrm{~V}$ vs. RHE. According to the Randles-Sevcik equation, the ESAs of Cu-In-1.5, Cu-In-7.5, Cu-In-15, Cu-In-30, and In-30 were determined and are listed in Table 1 . It can be clearly seen that as the 


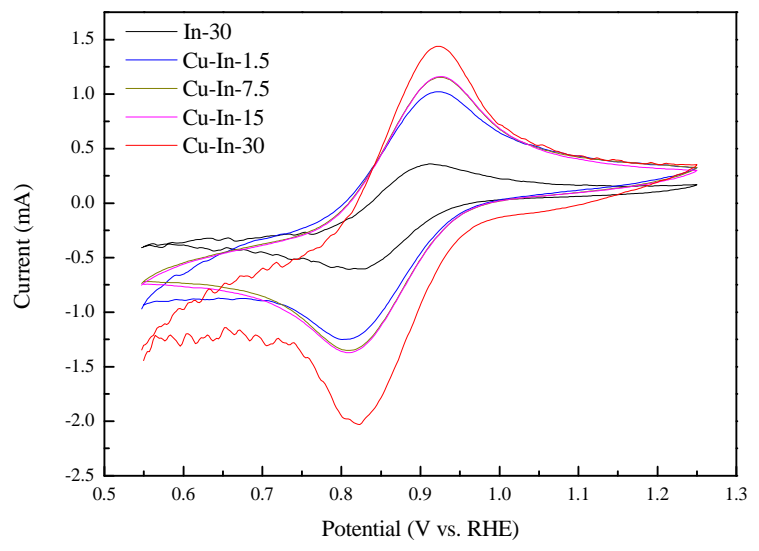

Fig. 5. Cyclic voltammograms of different catalysts for ESA measurement in $5 \mathrm{mmol} \mathrm{L}^{-1} \mathrm{~K}_{3} \mathrm{Fe}(\mathrm{CN})_{6}$ and $0.1 \mathrm{~mol} \mathrm{~L}^{-1} \mathrm{KCl}_{\text {solution. }}$

Table 1

ESA values for each catalyst measured by CV.

\begin{tabular}{lccccc}
\hline Catalyst & In-30 & Cu-In-1.5 & Cu-In-7.5 & Cu-In-15 & Cu-In-30 \\
\hline ESA $\left(\mathrm{cm}^{2}\right)$ & 2.4 & 5.7 & 6.3 & 6.4 & 8.7 \\
\hline
\end{tabular}

electrodeposition time for indium on the dendritic copper increases, the ESA of the catalyst also gradually increases, and $\mathrm{Cu}$-In-30 reaches the highest value of $8.7 \mathrm{~cm}^{2}$, whereas In-30 only reaches $2.4 \mathrm{~cm}^{2}$. In addition, Table S1 shows that the ESA-corrected current density of the $\mathrm{Cu}$-In-30 catalyst with the dendritic structure for formate $(4.8 \mathrm{~mA} \mathrm{~cm}-2)$ was also much higher than that of In-30 without the dendritic structure $(2.1$ $\mathrm{mA} \mathrm{cm}-2$ ), indicating that the dendritic structure improves the intrinsic activity, possibly due to the additional coordination unsaturated atoms.

To further emphasize the superiority of the $\mathrm{Cu}-\mathrm{In}-30$ electrode, we performed a stability test for $12 \mathrm{~h}$ (Fig. 6). The stability test was carried out in an $\mathrm{H}$-cell, and the concentration of formate in the electrolytic cell was increased continuously with the test time. Consequently, the $\mathrm{pH}$ was gradually decreased, resulting in the continuously increased current density and Faradaic efficiency of $\mathrm{H}_{2}$. We replaced the electrolyte with a fresh one at hourly intervals to avoid the effect of these negative factors on the test results. During the $12 \mathrm{~h}$ test, the Farada-

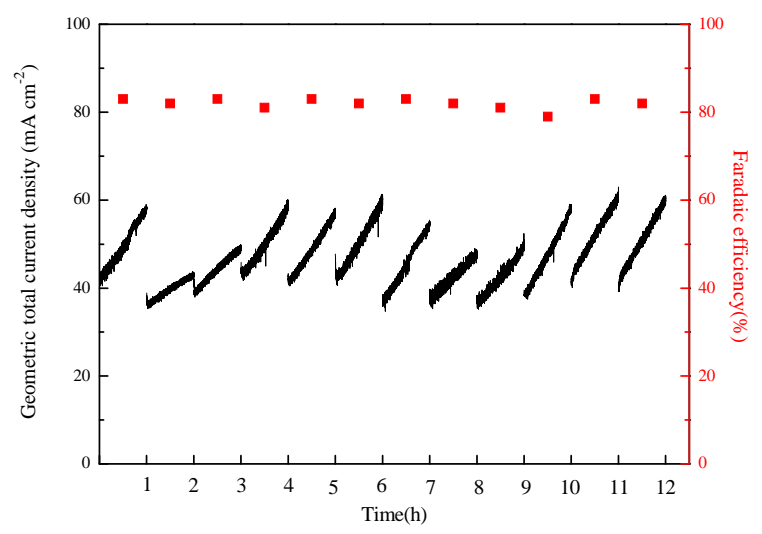

Fig. 6. Stability test of the $\mathrm{Cu}-\mathrm{In}-30$ catalyst measured at $-0.85 \mathrm{~V}$ vs. RHE for $\mathrm{CO}_{2} \mathrm{RR}$. ic efficiency of formate did not significantly decrease and maintained a value around $82.3 \%$, which further indicates the excellent catalytic performance of the $\mathrm{Cu}-\mathrm{In}-30$ catalyst.

\section{Conclusions}

Copper-indium bimetallic catalysts with a dendritic structure were prepared by a two-step electrodeposition method using hydrogen evolution as a template. The $\mathrm{Cu}-\mathrm{In}-30$ catalyst with the electrodeposition time of $30 \mathrm{~min}$ had the most electrochemical active sites; therefore, it could effectively improve the conversion of $\mathrm{CO}_{2}$ to formate. The $\mathrm{Cu}-\mathrm{In}-30$ catalyst exhibited a formate partial current density of $42.0 \mathrm{~mA} \mathrm{~cm}^{-2}$ and formate Faradaic efficiency of $87.4 \%$ at $-0.85 \mathrm{~V}$ vs. RHE, and maintained a stable performance for $12 \mathrm{~h}$ during the $\mathrm{CO}_{2} \mathrm{RR}$ measurement. The ESA-corrected formate partial current density of Cu-In-30 with the dendritic structure $\left(4.8 \mathrm{~mA} \mathrm{~cm}^{-2}\right)$ was higher than that of In-30 without the dendritic structure (2.1 $\mathrm{mA} \mathrm{cm}-2$ ), suggesting that the dendritic structure could increase the intrinsic activity. This work provides a feasible strategy to improve the selectivity and current density of $\mathrm{CO}_{2} \mathrm{RR}$ toward formate production.

\section{References}

[1] L. Liu, N. Tian, L. Huang, Y. H. Hong, A. Y. Xie, F. Y Zhang, C. Xiao, Z. Y. Zhou, S. G. Sun, Chin. J. Catal., 2016, 37, 1070-1075.

[2] G. Yang, Z. Yu, J. Zhang, Z. Liang, Chin. J. Catal., 2018, 39, 914-919.

[3] M. Liu, Y. J. Pang, B. Zhang, P. D. Luna, O. Voznyy, J. X. Xu, X. L. Zheng, C. T. Dinh, F. J. Fan, C. H. Cao, F. P. G. Arquer, T. S. Safaei, A. Mepham, A. Klinkova, E. Kumacheva, T. Filleter, D. Sinton, S. O. Kelley, E. H. Sargent, Nature, 2016, 537, 382-386.

[4] S. Gao, Y. Lin, X. C. Jiao, Y. F. Sun, Q. Q. Luo, W. H. Zhang, D. Q. Li, J. L. Yang, Y. Xie, Nature, 2016, 529, 68-71.

[5] J. Wu, X. D. Zhou, Chin. J. Catal., 2016, 37, 999-1015.

[6] C. Yan, L. Lin, G. Wang, X. Bao, Chin. J. Catal., 2019, 40, 23-37.

[7] P. D. Luna, R. Quintero-Bermudez, C. T. Dinh, M. B. Ross, O. S. Bushuyev, P. Todorović, T. Regier, S. O. Kelley, P. Yang, E. H. Sargent, Nat. Catal., 2018, 1, 103-110.

[8] M. G. Kibria, C. T. Dinh, A. Seifitokaldani, P. D. Luna, T. Burdyny, R. Quintero-Bermudez, M. B. Ross, O. S. Bushuyev, F. P. G. Arquer, P. D. Yang, D. Sinton, E. H. Sargent, Adv. Mater., 2018, 30, 1804867.

[9] P. C. Huang, M. Cheng, H. H. Zhang, M. Zuo, C. Xiao, Y. Xie, Nano Energy, 2019, 61, 428-434.

[10] Y. Fu, Y. Li, X. Zhang, Y. Liu, X. Zhou, J. Qiao, Chin. J. Catal., 2016, 37, 1081-1088

[11] W. Ju, A. Bagger, X. L. Wang, Y. L. Tsai, F. Luo, T. F. Möller, H. Wang, J. Rossmeisl, A. S. Varela, P. Strasser, ACS Energy Lett., 2019, 4, 1663-1671.

[12] S. Nellaiappan, S. Sharma, ACS Appl. Energy Mater., 2019, 2, 2998-3003.

[13] Y. Zhao, J. J. Liang, C. Y. Wang, J. M. Ma, G. G. Wallace, Adv. Energy Mater., 2018, 8, 1702524.

[14] Y. L. Zheng, P. Cheng, J. S. Xu, J. Y. Han, D. W. Wang, C. L. Hao, H. R. Alanagh, C. Long, X. H. Shi, Z. Y. Tang, Nanoscale, 2019, 11, 4911-4917.

[15] Q. F. Gong, P. Ding, M. Q. Xu, X. R. Zhu, M. Y. Wang, J. Deng, Q. Ma, N. Han, Y. Zhu, J. Lu, Z. X. Feng, Y. F. Li, W. Zhou, Y. G. Li, Nat. Commun., 2019, 10, 2807. 


\section{Graphical Abstract}

Chin. J. Catal., 2020, 41: 1393-1400 doi: 10.1016/S1872-2067(20)63577-X

Copper-indium bimetallic catalysts for the selective electrochemical reduction of carbon dioxide

Jiaqi Shao, Yi Wang, Dunfeng Gao, Ke Ye*, Qi Wang *, Guoxiong Wang Harbin Engineering University;

Dalian Institute of Chemical Physics, Chinese Academy of Sciences;

Dalian Jiaotong University
Due to the three-dimensional dendritic structure, the Cu-In-30 catalyst shows high performance in the $\mathrm{CO}_{2}$ electroreduction reaction with a formate partial current density of $42.0 \mathrm{~mA} \mathrm{~cm}-2$ and Faradaic efficiency of $87.4 \%$.

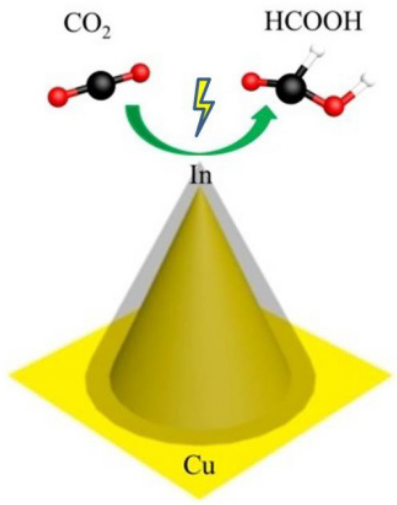

$\mathrm{C} \odot \mathrm{O} \odot \mathrm{HC}$
[16] X. F. Hou, Y. X. Cai, D. Zhang, L. Li, X. Zhang, Z. D. Zhu, L. W. Peng, Y. Y. Liu, J. L. Qiao, J. Mater. Chem. A, 2019, 7, 3197-3205.

[17] X. L. Zheng, P. D. Luna, F. P. G. Arquer, B. Zhang, N. Becknell, M. B. Ross, Y. F. Li, M. N. Banis, Y. Z. Li, M. Liu, O. Voznyy, C. T. Dinh, T. T. Zhuang, P. Stadler, Y. Cui, X. W. Du, P. D. Yang, E. H. Sargent, Joule, 2017, 1, 794-805.

[18] N. Zouaoui, B. D. Ossonon, M. Fan, D. Mayilukila, S. Garbarino, G. D. Silveira, G. A. Botton, D. Guay, A. C. Tavares, J. Mater. Chem. A, 2019, 7, 11272-11281.

[19] D. F. Gao, H. Zhou, J. Wang, S. Miao, F. Yang, G. X. Wang, J. G. Wang, X. H. Bao, J. Am. Chem. Soc., 2015, 137, 4288-4291.

[20] Y. Zhang, C. Ye, C. Guo, C. Gan, X. Tong, Chin. J. Catal., 2018, 39, 99-108.

[21] H. Mistry, R. Reske, Z. H. Zeng, Z. J. Zhao, J. Greeley, P. Strasser, B. R. Cuenya, J. Am. Chem. Soc., 2014, 136, 16473-16476.

[22] F. Adam, K. L. Sek, Chin. J. Catal., 2012, 33, 1802-1808.

[23] M. Valenti, N. P. Prasad, R. Kas, D. Bohra, M. Ma, V. Balasubramanian, L. Y. Chu, S. Gimenez, J. Bisquert, B. Dam, W. A. Smith, ACS Catal., 2019, 9, 3527-3536.

[24] C. M. Ding, A. L. Li, S. M. Lu, H. F. Zhang, C. Li, ACS Catal., 2016, 6, 6438-6443.

[25] X. Wang, J Chen, Chin. J. Catal., 2017, 38, 1818-1830.

[26] W. J. Dong, C. J. Yoo, J. L. Lee, ACS Appl. Mater. Inter., 2017, 9, 43575-43582.

[27] Z. B. Hoffman, T. S. Gray, K. B. Moraveck, T. B. Gunnoe, G. Zangari, ACS Catal., 2017, 7, 5381-5390.
[28] Q. Lai, N. Yang, G. Q. Yuan, Electrochem. Commun., 2017, 83, 24-27.

[29] W. C. Ma, S. J. Xie, X. G. Zhang, F. F. Sun, J. C. Kang, Z. Jiang, Q. H. Zhang, D. Y. Wu, Y. Wang, Nat. Commun., 2019, 10, 892.

[30] M. H. Zhu, P. F. Tian, J. Y. Li, J. C. Chen, J. Xu, Y. F. Han, ChemSusChem, 2019, 12, 3955-3959.

[31] Z. Tao, Z. Wu, X. Yuan, Y. Wu, H. Wang, Chin. J. Catal., 2019, 9, 10894-10898.

[32] K. Ye, F. Guo, Y. Y. Gao, D. M. Zhang, K. Cheng, W. P. Zhang, G. L. Wang, D. X. Cao, J. Power Sources, 2015, 300, 147-156.

[33] Y. S. Zhou, F. L. Che, M. Liu, C. Q. Zou, Z. Q. Liang, P. D. Luna, H. F. Yuan, J. Li, Z. Q. Wang, H. P. Xie, H. M. Li, P. Chen, E. Bladt, R. Quintero-Bermudez, T. K. Sham, S. Bals, J. Hofkens, D. Sinton, G. Chen, E. H. Sargent, Nat. Chem., 2018, 10, 974-980.

[34] X. L. Jiang, H. H. Wu, S. J. Chang, R. Si, S. Miao, W. X. Huang, Y. S. Li, G. X. Wang, X. H. Bao, J. Mater. Chem. A, 2017, 5, 19371-19377.

[35] L. Jia, H. Yang, J. Deng, J. Chen, Y. Zhou, P. Ding, L. Li, N. Han, Y. Li, Chin. J. Catal., 2019, 37, 497-500.

[36] J. B. Zhang, R. Yin, Q. Shao, T. Zhu, X. Q Huang, Angew. Chem. Int. Ed., 2019, 58, 5609-5613.

[37] H. P. Li, B. B. Zhang, W. Jiang, W. S. Zhu, M. Zhang, C. Wang, J. Y. Pang, H. M. Li, Green Energy Environ., 2017, 4, 38-48.

[38] X. Wu, J. Xu, G. Y. Chen, R. Fan, X. K. Liu, H. L. Xu, Green Energy Environ., 2017, 2, 387-392.

[39] S. Y. Yuan, P. L. Cui, Y. R. Zhang, H. Zhang, L. Huo, Y. J. Gao, Green Energy Environ., 2018, 3, 368-374.

\section{$\mathrm{Cu}-\mathrm{In}$ 二元金属催化剂上 $\mathrm{CO}_{2}$ 电化学还原}

郡加奇 ${ }^{\mathrm{a}, \mathrm{b}}$, 王 毅, 高敦峰 ${ }^{\mathrm{b}}$, 叶 克 ${ }^{\mathrm{a}, \mathrm{b}, *}$, 王 琪 ${ }^{\mathrm{c}, \# \text {, 汪国雄 }}{ }^{\mathrm{b}}$

a哈尔滨工程大学材料科学与化学工程学院超轻材料与表面技术教育部重点实验室, 黑龙江哈尔滨 150001

b 中国科学院大连化学物理研究所催化基础国家重点实验室, 洁净能源国家实验室(筹), 辽宁大连116023

c 大连交通大学材料科学与工程学院辽宁省轨道交通关键材料重点实验室, 辽宁大连 116028

摘要: 石油、天然气和煤等化石能源的转化利用不可避免排放大量的 $\mathrm{CO}_{2}$, 造成一系列生态和环境问题. $\mathrm{CO}_{2}$ 电化学还原可 以在温和反应条件下将 $\mathrm{CO}_{2}$ 转化为 $\mathrm{CO}$ 或甲酸等, 近年来受到研究者广泛关注, 但因 $\mathrm{CO}_{2}$ 具有很稳定的化学结构, $\mathrm{CO}_{2}$ 电化学 还原要求催化剂具有高的活性, 选择性和稳定性. 贵金属如金和钯可以有效地将 $\mathrm{CO}_{2}$ 转化为相应的燃料如 CO和甲酸等, 但 
贵金属昂贵的价格限制了其大规模应用, 所以迫使人们寻找非贵金属催化剂来替代它们. 铟及其合金被应用于 $\mathrm{CO}_{2}$ 电化学 还原生成甲酸, 但在低过电位下, 这些催化剂的电流密度和选择性都不理想. 铜基催化剂也能催化 $\mathrm{CO}_{2}$ 电化学还原生成甲 酸, 但在短时间内稳定性较差. 因此, 需要进一步提高 $\mathrm{In}$ 和 $\mathrm{Cu}$ 催化剂上 $\mathrm{CO}_{2}$ 电化学还原的电流密度和稳定性. 一种可能的解 决方案是构建 $\mathrm{Cu}-\mathrm{In}$ 双金属催化剂, 通过两者的协同作用, 有望提升在低过电位下 $\mathrm{CO}_{2}$ 电化学还原生成甲酸的电流密度和稳 定性.

在本工作中, 我们通过氢气模板法制备出具有树枝状结构的 $\mathrm{Cu}$, 然后在其表面均匀电沉积金属In. 通过两步电沉积法 制备出一种具有树枝状结构的Cu-In二元金属催化剂. 控制电沉积In的时长分别为 $1.5,7.5,15,30$ 和 60 min. 根据SEM及 EDX元素分布图谱可知, 随着电沉积 $I n$ 时间的增加, In在 $\mathrm{Cu}$ 表面的覆盖率逐渐增高. 我们还研究了 $\mathrm{In}$ 的电沉积时间与其电 化学活性表面积(ESA)之间的关系. 结果表明, In的电沉积时间与其电化学活性表面积成正比, 且当电沉积时间达到30 min 时, 电极具有最大的电化学活性表面积. 具有树枝状结构的Cu-In-30催化剂ESA数值为 $8.7 \mathrm{~cm}^{2}$, 而不具备树枝状结构的 In-30催化剂的ESA数值仅为 $2.4 \mathrm{~cm}^{2}$. 在 $-0.65 \mathrm{~V}$ vs. RHE至 $-1.05 \mathrm{~V}$ vs. RHE电位窗口中, 与其它催化剂相比, Cu-In-30催化 剂上 $\mathrm{CO}_{2}$ 电化学还原生成甲酸的法拉第效率最高可达 $87.4 \%$. 树枝状结构的Cu-In-30催化剂由于具有开放的三维结构, 所以 能够暴露出更多的活性位, 从而提高了催化剂的电化学性能. 在 $-0.85 \mathrm{~V}$ vs. RHE电位下, 甲酸分电流密度可达 $42.0 \mathrm{~mA}$ $\mathrm{cm}^{-2}$, 且具有较高的电化学稳定性 $(12 \mathrm{~h})$. 而不具有树枝状结构的In-30催化剂生成甲酸的法拉第效率为 $57.0 \%$, 且甲酸分电 流密度为 $4.6 \mathrm{~mA} \mathrm{~cm}^{-2}$.

关键词: $\mathrm{CO}_{2}$ 电还原; 铜; 铟; 电沉积; 甲酸

收稿日期: 2020-01-16. 接受日期: 2020-02-27. 出版日期: 2020-09-05.

*通讯联系人. 电话/传真: (0451)82569890; 电子信箱: yeke@hrbeu.edu.cn

\#通讯联系人. 电子信箱: qiwang@djtu.edu.cn

基金来源: 国家自然科学基金(21802124, 91845103); 辽宁省-沈阳材料科学国家研究中心联合研发基金(20180510035); 中国博士 后科学基金(2018M630307, 2019T120220); 黑龙江省自然科学基金优秀青年项目(YQ2019B002).

本文的电子版全文由Elsevier出版社在ScienceDirect上出版(http://www.sciencedirect.com/science/journal/18722067). 